\title{
BOAS-TYPE INEQUALITIES VIA SUPERQUADRATIC FUNCTIONS
}

\author{
Kristina Krulić, Josip PeČArić And DORA POKAZ
}

Abstract. We state and prove some new Boas type inequalities using the concept of superquadratic and subquadratic functions. We apply this result to refine the strengthened inequalities of the Hardy type.

Mathematics subject classification (2010): Primary 26D10, Secondary 26D15.

Keywords and phrases: Inequalities, Boas inequality, superquadratic function, subquadratic function, integral identities.

\section{REFERENCES}

[1] S. Abramovich, S. Banić And M. Matić, Superquadratic functions in several variables, J. Math. Anal. Appl. 327, 2 (2007), 1444-1460.

[2] S. Abramovich, G. Jameson and G. Sinnamon, Refining of Jensen's inequality, Bull. Math. Soc. Sci. Math. Roumanie (N.S.) 47, 95 (2004), 3-14.

[3] S. Abramovich, G. Jameson and G. Sinnamon, Inequalities for averages of convex and superquadratic functions, J. Inequal. Pure and Appl. Math.5, 4 (2004), Art. 91.

Online: http://www.emis.de/journals/JIPAM.

[4] S. Abramovich, K. Krulić, J. PeČarić, and L.-E. Persson, Some new refined Hardy type inequalities with general kernels and measures, Aequationes mathematicae. 79, 1-2 (2010), 157-172.

[5] R. P. BoAs, Some integral inequalities related to Hardy's inequality, J. Anal. Math. 23 (1970), 53-63.

[6] A. ČIŽMEŠIJA, S. HuSS AIN AND J. PEČARIĆ, Some new refinements of strengthened Hardy and Pólya-Knopp's inequalities, J. Funct. Spaces Appl. 7, 2 (2009), 167-186.

[7] A. ČIŽMeŠIJA, J. PeČARIĆ, AND L.-E. Persson, On strengthened Hardy and Pólya-Knopp's inequalities, J. Approx. Theory 125 (2003), 74-84.

[8] A. ČIŽMešIJa, J. PeČARIĆ, AND D. PoKAZ, A new general Boas-type inequality and related Cauchy-type means, Math. Inequal. Appl., to appear.

[9] G. H. HARDY, Note on a theorem of Hilbert, Math. Z. 6 (1920), 314-317.

[10] G. H. HARDY, Notes on some points in the integral calculus LX: An inequality between integrals (60), Messenger of Math. 54 (1925), 150-156.

[11] G. H. HARDY, Notes on some points in the integral calculus LXIV, Messenger of Math. 57 (1928), $12-16$.

[12] S. KAijser, L.-E. Persson, And A. ÖBerg, On Carleman and Knopp's Inequalities, J. Approx. Theory 117 (2002), 140-151.

[13] K. Krulić, J. Pečarić, And L.-E. Persson, Some new Hardy type inequalities with general kernels, Math. Inequal. Appl. 12 (2009), 473-485.

[14] A. Kufner, L. Maligranda, And L.-E. Persson, The Hardy Inequality - About its History and Some Related Results, Vydavatelsky Servis Publishing House, Pilsen, 2007.

[15] D. LuOR, Modular inequalities for the Hardy-Littlewood averages, Math. Inequal. Appl. 13, 3 (2010), 635-642.

[16] J. A. Oguntuase And L.-E. Persson, Refinement of Hardy's inequalities via superquadratic and subquadratic functions, J. Math. Anal. Appl. 339 (2008), 1305-1312.

[17] J. A. Oguntuase, L.-E. Persson, E. K. Essel and B. A. Popoola, Refined multidimensional Hardy-type inequalities via superquadracity, Banach J. Math. Anal. 2, 2 (2008), 129-139. 
[18] J. E. PeČArić, F. Proschan, And Y. L. Tong, Convex functions, partial orderings, and statistical applications, Academic Press, San Diego, 1992.

[19] J. XIAO, $L^{p}$ and BMO Bounds of Weighted Hardy-Littlewood Averages, J. Math. Anal. Appl. 262 (2001), 660-666. 